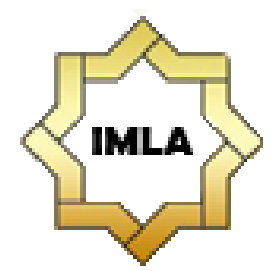

\author{
Al-Ta'rib \\ Jurnal Ilmiah Program Studi Pendidikan Bahasa Arab \\ IAIN Palangka Raya \\ Vol. 8, No. 1, June 2020, 103-116 \\ p-ISSN 2354-5887 | e-ISSN 2655-5867
}

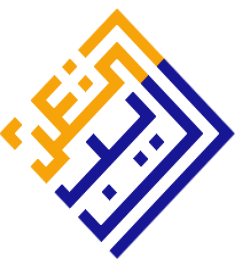

\title{
PEMBELAJARAN QAWAID: PERSPEKTIF TEORI KOGNITIF PADA PONDOK PESANTREN RAUDHATUT THALIBIN KALIMANTAN SELATAN
}

\author{
Zam Zam Rasyidi \\ Sekolah Tinggi Ilmu Al-Qur'an Amuntai, Indonesia \\ E-mail: zamzamrasyidi@gmail.com
}

\begin{abstract}
This study aims to know the Qawa'id learning process from the perspective of Cognitive Theory at the Raudhatut Thalibin Islamic boarding school in the village of Tayur Hulu Sungai Utara (HSU) of South Kalimantan, Indonesia and to know the Qawa'id learning method with the Cognitive Theory perspective in the boarding school. This type of study is descriptive qualitative one. Data are collected through interview, observation, and documentation. The collected data was analyzed by means of the interactive model (interactive model) of Miles and Huberman. The results of this study reveal that the steps of Qowaid learning in the perspective of cognitive theory are as follows. (1) The teacher explains in advance the material to be taught using the deductive method. (2) The teacher gives examples of what has been explained before. (3) The teacher asks the students to memorize qowaid and vocabulary contained in the sentences or text they are learning. (4) The teacher will not move from one rule to another before the students really understand one rule first. The Qowaid learning methods used in the perspective of cognitive theory, namely; (1) the Nahw wa Tarjamah Method (Grammar Translation), (2) the deductive method, (3) the question and answer method, (4) and the bahtsul masa'il method.
\end{abstract}

Keywords: Qawaid Learning; Cognitive Theory Perspective

Abstrak
Penelitian ini bertujuan untuk mengetahui proses pembelajaran Qawa'id persepektif
Teori Kognitif pada pondok pesantren Raudhatut Thalibin desa Tayur Hulu Sungai
Utara (HSU) Kalimantan Selatan serta mengetahui metode pembelajaran Qawa'id
persepektif Teori Kognitif yang digunakan pada pondok pesantren tersebut. Jenis
penelitian ini adalah penelitian kualitatif deskriptif. Dan tehnik pengumpulan data
dilakukan dengan wawancara, observasi, dan dokumentasi. Data yang terkumpul
dianalisis dengan model interaktif (model interactive) Miles dan Huberman. Hasil
penelitian ini mengungkapkan bahwa Langkah-langkah pembelajaran Qowaid
dalam perspektif teori kognitif adalah sebagaimana berikut: (1) Guru menjelaskan
terlebih dahulu materi yang akan diajarkan menggunakan metode deduktif, (2)
Guru memberikan contoh-contoh dari apa yang telah dijelaskan sebelumnya, (3)


Guru meminta para santri untuk menghafal qowaid dan kosakata yang terdapat dalam kalimat atau teks yang mereka pelajari, (4) Guru tidak akan berpindah dari satu kaidah ke kaidah lain sebelum para santri benar-benar paham dengan satu kaidah terlebih dahulu. Adapun metode-metode pembelajaran Qowaid yang digunakan dalam perspektif teori kognitif, yakni (1) Metode Nahw wa Tarjamah (Gramatika Terjemah), (2) Metode deduktif, (3) Metode tanya jawab, (4) dan metode bahtsul masa'il.

\section{Kata Kunci: Pembelajaran Qawa'id; Perspektif Teori Kognitif}

\section{Pendahuluan}

Pembelajaran bahasa Arab bertujuan untuk memahami Al-Quran dan Hadis serta ilmu agama Islam yang tertuang dalam kitab-kitab klasik maupun modern. Penggunaan Bahasa Arab yang baik dan benar tidak lepas kaitannya dengan penguasaan pada aspek kaidah-kaidah Bahasa Arab (Qawaid Al-Nahwiyyah). Oleh sebab itu, Qawaid Al-Nahwiyyah merupakan salah satu unsur penting dari pembelajaran bahasa Arab yang berimplikasi pada pemahaman apa yang didengar (Istima'), dibicarakan (Kalam), dibaca (Qiro'ah), dan ditulis (Kitabah) secara baik dan benar (Hawamadah, 2010).

Namun, fenomena problematika dalam pembelajaran Qawaid sampai saat ini masih belum menemukan titik terang. Fenomena ini dilandasi oleh dua alasan utama yakni: (1) kurangnya motivasi peserta didik dalam belajar bahasa Arab (Fahrurrozi, 2014), (2) dan penggunaan metode pembelajaran yang tidak inovatif dan variatif (Zaenudin \& Asror, 2019).

Berbagai macam upaya dilakukan sebagai wujud perhatian dalam menyikapi problematika tersebut (Sa'adah, 2019). Beberapa eksperimen diselenggarakan sebagai uji efektifitas sebuah metode dalam pembelajaran qawaid (Rohayati, 2018) \& (Amin, 2018). Begitu juga halnya pengembangan sebuah media pembelajaran interaktif yang dilakukan oleh Kurniawan (2019) sebagai solusi problematika yang terjadi pada pembelajaran Qawaid (Kurniawan, 2019). Namun, peneliti berpendapat bahwa upaya-upaya tersebut masih belum memberikan hasil yang signifikan jika diterapkan di Pondok Pesantren Salafiyah (Konvensional) yang sampai saat ini masih konsisten dengan penggunaan metode gramatikal dan terjemah (Qawaid wa Tarjamah) pada pembelajaran Qawaid (Aliyah, 2018). Di sisi lain, mayoritas Pondok Pesantren baik konvensional maupun modern menerapkan larangan penggunaan alat elektronik kepada seluruh santri sehingga tidak memungkinkan penggunaan media dalam pelaksanaan pembelajaran.

Hal ini juga berpengaruh besar terhadap proses pembelajaran Bahasa Arab secara umum dan khususnya pada pelajaran Qowaid di luar Pondok Pesantren mengingat mayoritas pengajar Bahasa Arab baik di tingkat sekolah dasar, menengah, maupun Perguruan Tinggi adalah alumni Pondok Pesantren. Maka dari itu, perlu adanya teori khusus dalam pelaksanaan pembelajaran Qawaid khususnya di Pondok Pesantren Salafiyah (konvensional).

Salah satu terobosan teori yang dapat digunakan dalam pembelajaran Qawaid adalah teori pembelajaran kognitif. Teori kognitif menekankan bahwa aktifitas belajar merupakan suatu proses yang terjadi dalam akal pikiran peserta didik dari bagaimana upaya dalam memperoleh pengetahuan, 
mengorganisasikannya serta menyimpannya dalam ingatan peserta didik (Schunk \& DiBenedetto, 2020). Dalam teori kognitif, aktifitas belajar tidak hanya melibatkan stimulus dan respon namun melibatkan proses yang komplek dalam aktifitas berpikir (Anidar, 2017). Bahkan Aliyah dalam hasil penelitiannya mengungkapkan bahwa penerapan teori kognitif sangat efektif terhadap penguasaan Qawaid peserta didik (Aliyah, 2018). Hal ini disebabkan oleh karakteristik dari teori Kognitif yang menekankan pada aspek kontruksi dan menciptakan pengalaman yang dialami oleh peserta didik, tidak hanya sebatas mengulang dan meniru apa yang telah mereka peroleh (Gredler, 2012).

Dari fakta ini, tentunya teori kognitif sangat relevan dengan pembelajaran qawaid yang menekankan peserta didik pada proses berpikir secara mendalam seperti menganalisis kalimat, mengetahui kedudukan kata dalam kalimat serta menghapal kaidah-kaidah nahwiyyah.

Salah satu lembaga pendidikan yang menerapkan teori kognitif dalam pembelajaran qawaid Al-Nahwiyyah adalah Pondok pesantren Raudhatut Thalibin Kabupaten Hulu Sungai Utara (HSU) Kalimantan Selatan. Pondok Pesantren ini didirikan pada tahun 2000 dibawah pimpinan K. H. Ahmad Mu'thi dan telah memiliki banyak santri yang berasal dari Kalimantan Selatan, Kalimantan Tengah, Kalimantan Timur, bahkan dari Sumatra Utara.

Dari hasil observasi, pondok pesantren tersebut mengkombinasikan beberapa metode yang memiliki karakteristik pada teori kognitif seperti aspek penguatan kemampuan berfikis logis, mengkonstruksikan sebuah pengalaman belajar sebagai upaya pemecahan masalah (problem solving) serta menghafal materi-materi yang telah dipelajari dalam proses pembelajaran. Beberapa metode tersebut adalah qawaid wa al-tarjamah, metode deduktif, metode tanya jawab, dan metode bahtsul masaa'il. Kombinasi dari beberapa metode tersebut berimplikasi pada stimulus aktifitas berpikir santri secara mendalam baik pada pemecahan masalah maupun menghafal materi yang ada pada pelajaran Qawaid.

Dari kombinasi beberapa metode tersebut, pembelajaran Qawaid di Pondok Pesantren Raudhatut Thalibin dapat dikatakan berhasil. Hal itu dibuktikan dengan dokumen prestasi 37 santri di bidang perlombaan Mutsabaqah Qira'atil Kitab (MKQ) yang diselenggarakan di tingkat Kabupaten maupun Provinsi. Banyak santri alumni Pondok Pesantren Raudhatut Thalibin yang lulus seleksi/tes penerimaan di perguruan tinggi dalam maupun luar negeri melalui jalur prestasi pada Qira'atul Kitab Turats (Kitab Kuning).

Maka dari itu, penelitian ini penting untuk dikaji lebih dalam sebagai cikal bakal pembaharuan dari sistem pembelajaran Qowaid di mayoritas pondok pesantren Salafiyah (klasik) di Indonesia yang masih kental dengan hanya menggunakan metode qawaid wa al-tarjamah.

\section{Teori Kognitif Pada Pembelajaran Bahasa}

Strategi pembelajaran kognitif pada pembelajaran bahasa sebagai berikut: a) Siapa pun yang ingin belajar bahasa harus terbiasa dengan tata bahasa, aturan tata bahasa dan morfologis yang disebut Chomsky sebagai kompetensi linguistik. b) Guru harus mengarahkan siswa-siswanya untuk mengambil manfaat sebanyak mungkin dari informasi yang mereka dapatkan sebelumnya mengenai subjek yang akan dipelajari, baik merupakan topik dalam tata bahasa, membaca atau menulis, dan jika siswa tidak memiliki informasi sebelumnya terkait dengan topik baru atau 
tidak terkait dengan baik, maka guru harus membantunya dalam hal ini melalui diskusi. c) Guru tidak boleh pindah dari kaidah tertentu ke kaidah yang lain sampai dia yakin murid-muridnya memahaminya dengan baik, bahkan jika perlu menggunakan terjemahan, kemudian melatih mereka untuk menerapkan aturanaturan ini dengan tujuan mendorong peserta didik untuk menemukan kata-kata, frasa dan struktur baru. d) Mengubah ruang kelas menjadi suasana yang mirip dengan suasana sosial alam asli dari budaya bahasa target, dan membuka jalan bagi semua siswa untuk menyampaikan saran dan berpartisipasi dalam diskusi, dan bahwa peran guru dibatasi pada instruksi, bimbingan, mengangkat masalah dan menyajikan topik kepada siswa (Ma'arif, 2010).

\section{Langkah-langkah pembelajaran bahasa menurut perspektif teori kognitif}

Langkah-langkah pembelajaran yang sesuai dengan teori kognitif adalah sebagai berikut: 1) mempresentasikan materi baru dengan metode deduktif, 2) pelatihan terhadap beberapa bentuk bahasa yang disajikan dalam konteks kalimat, 3) mempelajari beberapa teks bacaan yang didengar serta memberikan kesempatan bagi siswa untuk mengkomunikasikan ide-ide mereka kepada orang lain (Rusydy Ahmad Tu'aimah, 1989).

\section{Metode}

Penelitian ini menggunakan pendekatan kualitatif. Pendekatan kualitatif menurut Bogdan dan Taylor (1975) ialah prosedur penelitian yang menghasilkan data deskriptif berupa kata-kata tertulis atau lisan dari orang-orang dan prilaku yang dapat dialami (Moleong \& Creswell, 2006). Adapun jenis penelitiannya adalah deskriprif analisis.

Adapun sember data pada penelitian ini adalah guru qawa'id dan para Santri kelas 10 pada pondok pesantren Raudhatut Thalibin desa Tayur (HSU) Kalimantan Selatan baik berupa dokumentasi, video pembelajaran qawa'id, maupun hal lainnya yang berkaitan dengan penelitian.

Untuk mendapatkan data yang dibutuhkan pada penelitian, peneliti menggunakan teknik observasi, wawancara dan dokumentasi. Peneliti melakukan teknik observasi terhadap kelas 10 di pondok pesantren Raudhatut Thalibin desa Tayur (HSU) Kalimantan Selatan serta menggunakan teknik wawancara dengan guru qawa'id di kelas tersebut. Hal itu dilakukan untuk mencari data berupa proses pembelajaran qawaid serta metode dalam perspektif Teori Kognitif. Sedangkan dokumentasi digunakan untuk mencari data seperti visi, misi, kurikulum, serta bukti prestasi yang telah diraih oleh para santri di bidang (qiraah) membaca kitab kuning (klasik).

Bentuk analisis data yang digunakan dalam penelitian ini adalah model analisis data interaktif Milles dan Huberman yaitu sebagai berikut: (Sugiyono, 2015).

1. Reduksi data

Reduksi data adalah penarikkan kesimpulan dari suatu yang umum kepada yang bersifat khusus. Karena data yang didapat dari lapangan sangat banyak, kompleks serta rumit. Oleh karena itu data tersebut perlu untuk direduksi hingga ditarik kesimpulan data yang dibutuhkan saja yaitu mengenai data tentang proses pembelajaran qawaid sera metode pembelajaran yang dugunakan oleh guru. 
2. Display data

Display atau penyajian data dalam penelitian kualitatif, data bisa diuraikan secara singkat, bagan atau sejenisnya. Namun penyajian data yang sering terjadi pada penelitian kualitatif adalah berupa teks yang bersifat naratif. Pada penelitian ini peneliti menggunakan display data yang berupa penyajian teks naratif. Dengan menyajikan data berupa proses serta metode pembelajaran qawaid yang digunkan oleh guru.

3. Verifikasi data

Setelah peneliti melakukan penarikkan kesimpulan lalu peneliti mempelajari serta memahami kembali data-data dari hasil penelitian yang didapat, sehingga kesimpulan yang diperoleh dapat menjawab rumusan masalah yang telah dirumuskan sebelumnya.

Untuk lebih jelasnya, analisis data kualitatif dengan menggunakan model Miles dan Huberman dapat diamati pada bagan berikut:

\section{Bagan 1.}

Model Analisis Data Interaktif Miles dan Huberman

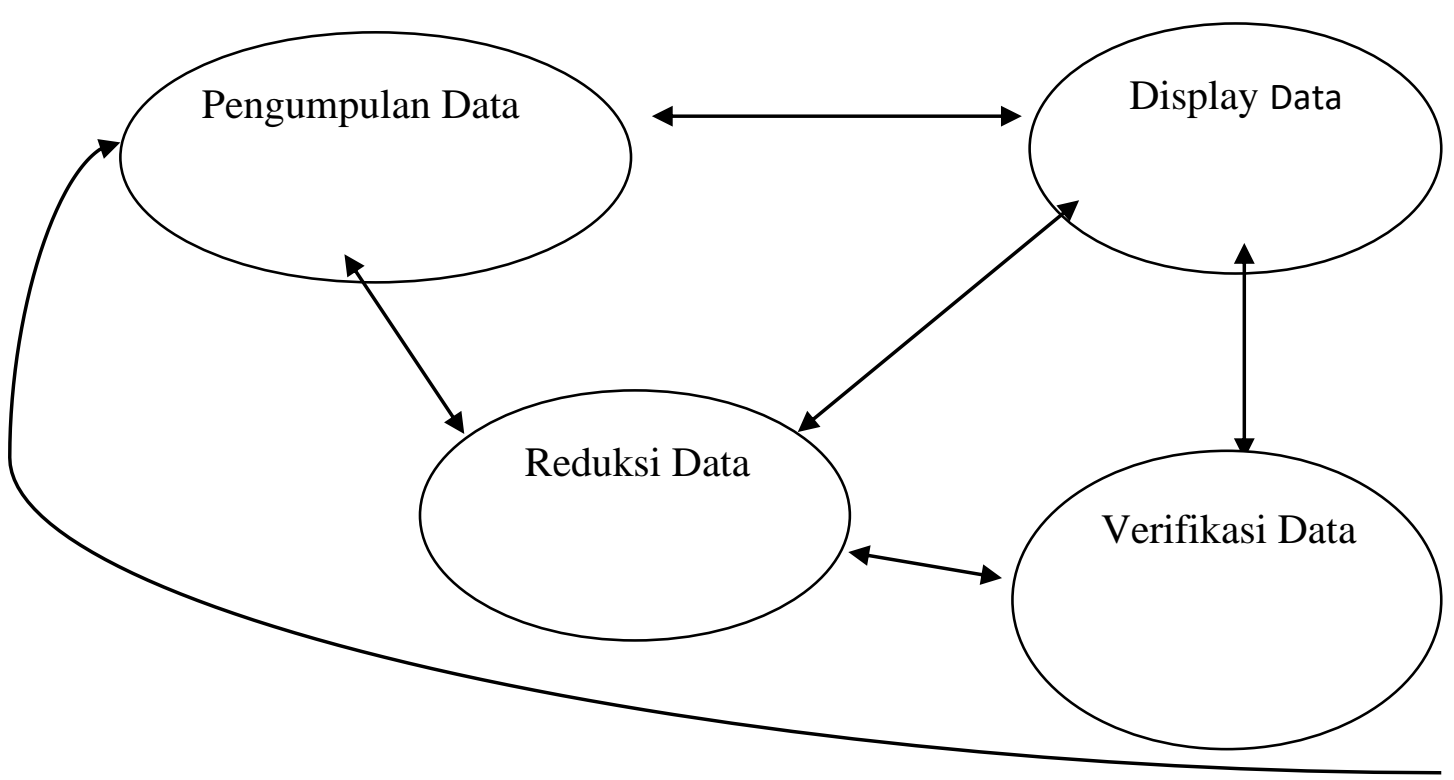

Untuk menguji keabsahan data, peneliti menggunakan triangulasi. Triangulasi adalah teknik pemeriksaan keabsahaan data dengan memanfaatkan sesuatu yang lain di luar data tersebut, tujuannya adalah untuk pengecekan atau pembanding terhadap data yang bersangkutan (Moleong \& Creswell, 2006). Teknik triangulasi yang banyak digunakan adalah pemeriksaan keabsahan data melalui sumber yang lainnya. Denzin (dalam Moloeng, 1990: 178), membedakan 
empat macam triangulasi sebagai teknik pemeriksaan keabsahan data yang memanfaatkan sumber, metode, penyidik dan teori (Nugrahani \& Hum, 2014). Pada penelitian ini peneliti menggunakan pemeriksaan data pada sumber-sumber lainnya agar data yang dihasilkan benar-benar valid seperti melakukan wawancara dengan kepala sekolah, beberapa dari para murid di kelas 10 pondok pesantren Raudhatut Thalibin, serta melakukan wawancara dengan guru atau pengajar qawaid itu sendiri.

\section{Hasil Penelitian dan Pembahasan \\ Proses pembelajaran Qawa'id persepektif Teori Kognitif pada pondok pesantren Raudhatut Thalibin desa Tayur Hulu Sungai Utara (HSU) Kalimantan Selatan}

Pembelajaran Qawaid pada pondok pesantren Raudhatut Thalibin adalah mata pelajaran wajib yang harus diikuti oleh semua santri. K.H Ahmad Mu'thi sebagai pendiri serta pengasuh pondok Raudhatut Thalibin mengatakan bahwa ilmu nahwu yang mereka pelajari bertujuan untuk penguasaan membaca kitab kuning. Dalam mempelajari ilmu qawa'id harus lebih menekankan pada praktik tersendiri, namun pada proses pembelajarannya guru juga memberikan kaidahkaidah bahasa Arab agar Santri mempunyai kemampuan menggunakan bahasa Arab untuk berkomunikasi sehari-hari. Sebagaimana bahasa asing lainnya bahasa Arab juga mempunyai aturan-aturan yang perlu dikuasai oleh setiap penuntutnya.

Melalui observasi terhadap pembelajaran Qawa'id, serta wawancara dengan guru pengajar Qawa'id di kelas 10 pondok pesantren Raudhatut Thalibin Tayur dapat diketahui bahwa proses pembelajaran di pondok tersebut ialah menggunakan sistem terpisah-pisah (nizhamul furu'), yaitu pembelajaran bahasa maupun unsur-unsurnya dibagi menjadi beberapa bagian mata pelajaran. Misalnya antara kemahiran-kemahiran berbahasa diajarkan secara terpisah tidak diajarkan secara bersama-sama. Begitu juga pada unsur-unsur berbahasa, misalnya mata pelajaran nahwu, sharaf, insya dan lain sebagainya diajarkan secara terpisah. Sistem seperti ini umum digunakan pada beberapa pondok pesantren yang berbasis salaf (Makruf, 2016).

Pada setiap pembelajaran umumnya terdapat perencanaan pembelajaran atau yang disebut dengan silabus, RPP dan sejenisnya. Namun pada pembelajaran qawa'id di pondok pesantren Raudhatut Thalibin ini peneliti tidak menemukan silabus maupun RPP, hanya saja guru qawa'id di pondok tersebut mengukur ketercapaian pembelajaran qawa'id itu sendiri dengan berpegang pada penguasaan Santri terhadap isi buku yang digunakan, yaitu buku Is'afut Thalibin (إسعاف الطالبين). Cara pembelajaran di pondok pesantren ini masih sangat kental dengan gaya pesantren klasik.

melalui wawancara dengan pengajar qawa'id serta kepala sekolah, dapat diketahui bahwa tujuan dari diajarkannya ilmu qawa'id di pondok tersebut ialah agar para santri atau Santrinya terampil dalam kemahiran membaca, lebih khususnya keterampilan membaca kitab kuning.

Adapun langkah-langkah pembelajaran qawa'id pada pondok pesantren Raudhatut Thalibin Tayur (HSU) sebagai berikut: 
Pertama, Pada awal memberikan pelajaran baru, guru memberikan atau menjelaskan kaidah terlebih dahulu dengan metode deduktif. Misalnya pada bab Fa'il, guru menjelaskan kaidah "الفاعل هو الاسم المرفوع المذكور قبله فعله". Menurut Ausubel di dalam Mona Ekawati, penyampaian materi pembelajaran hendaknya diurutkan dari Umum ke khusus agar proses belajar lebih bermakna bagi Santri (D. Ekawati, 2019).

Kedua, setelah pemberian kaidah serta penjelasannya telah selesai lalu guru memberikan contoh-contoh dari pembahasan tersebut. Hal semacam ini sesuai dengan prosedur pembelajaran bahasa Arab menurut persepektif teori kognitif, Rusydi Ahmad Thuaimah di dalam bukunya menyebutkan bahwa langkah-langkah pembelajaran bahasa menurut teori kognitif adalah sebagai berikut:

بيدأ الدرس بشرح القو اعد ثُ ضرب أمثلة عليها. أي تتبع الطريقة الاستنباطبة "

"في تعليم اللغة

Pelajaran dimulai dengan menjelaskan kaidah-kaidah kemudian pemberian contoh yakni dilaksanakan dengan metode deduktif pada pembelajaran Bahasa (Tu'aimah, 2010).

Ketiga, guru juga meminta para santri untuk menghapal kaidah-kaidah nahwu serta menghapalkan kosa kata yang terdapat dalam kalimat atau teks yang mereka pelajari.

Keempat, guru tidak akan berpindah dari satu kaidah ke kaidah lain sebelum para Santri benar-benar paham dengan satu kaidah terlebih dahulu. Hal ini sejalan dengan strategi teori kognitif dalam pembelajaran Bahasa. Pada pembelajaran kognitifistik seorang guru menyajikan proses pembelajaran menyesuaikan dengan tingkat perkembangan kognitif Santri. Tujuannya adalah agar peserta didik mampu mengembangkan kemampuan kognitifnya secara maksimal serta mengantarkan mereka kepada tahap kognitif yang lebih tinggi (Rosyid \& Baroroh, 2019).

Adapun evaluasi pembelajaran qawa'id di pondok pesantren Raudhatut Thalibin Tayur (HSU) menggunakan dua teknik evaluasi yaitu evaluasi tes dan non tes (pengawasan secara langsung). Hal ini sesuai dengan keputusan Permendiknas no. 20 tahun 2017 mengenai standar penilaian pendidikan bahwa standar penilaian hasil belajar harus menggunakan berbagai teknik yang disesuaikan dengan karakteristik kompetensi dan tingkatan perkembangan Santri. Teknik tersebut yaitu: 1) Teknik tes berupa tes tertulis, lisan, praktik atau tes kinerja. 2) Teknik observasi atau pengamatan langsung yang dilakukan selama proses pembelajaran berlangsung atau diluar pembelajaran sekalipun. 3) Teknik penugasan, baik perorangan maupun tugas kelompok yang berbentuk tugas atau proyek.

Selain itu, evaluasi dalam pembelajaran qawa'id di pesantren Raudhatut Thalibin Tayur (HSU) terdapat dua jenis evaluasi yakni: 1) Evaluasi furmatif yaitu yang dilaksanakan setiap selesai pembahasan, setiap seminggu sekali dan atau setiap satu bulan sekali (diluar evaluasi akhir semester). 2) Evaluasi sumatif yang dilaksanakan setiap akhir semester.

Setelah guru memberikan evaluasi berbentuk latihan atau tes, dimana setelah tugas latihan itu dikerjakan dan dikoreksi oleh guru, guru selalu meberikan umpan balik atau memberikan jawaban yang benar kepada semua santri jika dari 
tugas mereka terdapat kesalahan dalam menjawab. Pemberian umpan balik ini bertujuan agar suatu kesalahan tidak bersemayam di benak santri. Ini sesuai dengan teori kognitif karena sebagian dari tujuan teori kognitif ialah pembenaran terhadap kesalahan berbahasa yang merupakan bagian terpenting pada kegiatan berbahasa di dalam kelas (Ushaily, A. A., n.d.).

\section{Metode Pembelajaran Qawaid persepektif Teori Kognitif pada pondok pesantren Raudhatut Thalibin desa Tayur Hulu Sungai Utara (HSU) Kalimantan Selatan}

Metode pembelajaran berfungsi untuk mencapai suatu tujuan pembelajaran itu sendiri, tanpa metode mustahil suatu tujuan pembelajaran akan tercapai (Maijala, 2020). Oleh karena itu metode pembelajaran menempati tempat yang sangat penting dalam suatu pembelajaran. Dari hasil observasi serta wawancara dengan pengajar qawa'id (juga kepada kepala sekolah dan para murid) pada pondok pesantren Raudhatut Thalibin desa Tayur (HSU) Kalimantan Selatan, dapat diambil kesimpulan bahwa pada pembelajaran qawa'id terdapat beberapa metode pembelajaran. Metode-metode tersebut adalah metode Nahwi wa Tarjamah (gramatika terjemah), metode Deduktif, metode Tanya Jawab, dan metode Bahsul Masail. Berikut penjelasannya dalam persepektif teori kognitif:

\section{Metode Nahw Wa Tarjamah (gramatika terjemah)}

Metode Nahw Wa Tarjamah (gramatika terjemah) merupakan salah satu metode yang melibatkan proses berpikir secara mendalam. Menurut Thuaimah metode ini berperan sebagai sarana untuk mengembangkan kemampuan akal dan cara berpikir (Tu'aimah, 2010). Peneliti berpendapat bahwa metode ini sangat sesuai dengan metode perspektif kognitif, dimana metode ini melibatkan akal secara mendalam serta lebih menekankan bahwa belajar merupakan suatu proses yang terjadi dalam akal pikiran Santri dari bagaimana cara memperoleh pengetahuan, mengorganisasikannya serta menyimpannya dalam ingatan para santri.

Di sisi lain, Thuaimah, dkk menambahkan dalam kitabnya yang berjudul $A l$ Marji' Fi Manahiji Ta'limil Lughah Al Arabiyyah Lin Nathiqina Bilughatil Ukhra, bahwa penggunaan metode Nahwi Wa Tarjamah (gramatika terjemah) dalam pembelajaran bahasa kedua terhadap peserta didik akan memberikan kontribusi yang sangat baik di bidang kemampuan membaca dan menulis dalam waktu yang sangat singkat. Jika dibandingkan dengan mereka yang menggunakan metode lain (Tu'aimah, 2010).

Kesimpulannya adalah bahwa penggunaan metode Nahwi Wa Tarjamah (gramatika terjemah) pada pembelajaran Qawa'id untuk mengembangkan kemampuan membaca dan menulis sangat efektif. Hal ini terbukti membantu pondok pesantren Raudhatut Thalibin dalam pencapaian visi dan misi ponpes yaitu membentuk insan yang terampil dalam membaca kitab kuning klasik. Bukti lainnya adalah pondok pesantren Raudhatut Thalibin berhasil dalam mengembangkan kemampuan membaca para santri, sehingga sering meraih prestasi pada perlombaan-perlombaan membaca kitab.

\section{Metode Deduktif}

Metode Deduktif adalah salah satu cara berpikir yang digunakan untuk menjangkau dari hal yang sudah diketahui ke yang tidak diketahui, berpikir dari kaidah umum kepada yang lebih khusus yakni dari aturan-aturan yang umum 
kepada yang lebih khusus (M. Ekawati, 2019). Berpikir deduktif ialah merupakan salah satu bagian dari komponen kognitif serta merupakan proses mental tentang bagaimana seseorang dalam memecahkan masalah, menalar, menganalisis, dan menarik sebuah kesimpulan (Ramelan, 2008). Dimana berpikir itu sendiri secara umum didefinisikan sebagai proses kognitif, yakni adanya aktivitas mental Santri untuk memperoleh suatu pengetahuan (Nugraha, 2018).

Pondok pesantren Raudhatut Thalibin desa Tayur Hulu Sungai Utara (HSU) Kalimantan Selatan menggunakan metode deduktif terhadap Santri tingkat menengah pada pembelajaran qawaid.

\section{Metode Tanya Jawab}

Metode Tanya jawab merupakan metode pembelajaran yang melibatkan proses komunikasi secara langsung yang bersipat two way traffic karena pada saat itu terjadilah dialog antara guru dan Santri, guru bertanya Santri menjawab atau Santri bertanya guru menjawab, dalam komunikasi ini terlihat adanya hubungan timbal balik secara lansung antara guru dan Santri.

Penerapan metode tanya jawab pada pembelajaran qawaid di pondok pesantren Raudhatut Thalibin desa Tayur Hulu Sungai Utara (HSU) Kalimantan Selatan yaitu guru menyuruh serta mewajibkan kepada setiap santri untuk membuat beberapa pertanyaan dan membacakannya di depan kelas, kemudian dengan bimbingan guru, semua Santri mencari jawabannya dari beberapa referensi kitab yang mereka bawa.

Dari penerapan metode Tanya jawab ini dapat dilihat bahwa Santri mendapatkan kesempatan untuk menggunakan kemampuan berpikir kritis serta membangun pengetahuan mereka. Hal ini merupakan bagian dari teori kognitif. Menurut pandangan teori kognitif bahwa pendidikan yang sebenarnya adalah dengan memberikan kesempatan kepada peserta didik untuk mengeksploitasi kemampuan mental mereka, membangun pengetahuan mereka, dan "kesadaran akan pengalaman dan rangsangan lingkungan baru bukan hanya proses perekaman dari apa yang dirasakan.

\section{Metode Bahtsul Masa'il}

Penerapan metode bahtsul masa'il pada pembelajaran qawaid di pondok pesantren Raudhatut Thalibin desa Tayur Hulu Sungai Utara (HSU) Kalimantan Selatan mengikuti beberapa langkah berikut yakni: 1. Guru mengarahkan para santri serta membimbing mereka untuk memecahkan suatu permasalahan yang telah ditentukan (dalam ranah ilmu qawaid). Misalnya guru memberikan tema tentang hal (حال), dari satu tema ini muncul beberapa perkembangan permasalahan yaitu: kenapa hal tersbut mansub (منصوب), apa saja syarat-syarat hal? dan lain sebagainya. 2. Untuk memecahkan permasalahan tersebut para santri akan bermusyawarah satu sama lain dengan menggali jawaban dari berbagai referensi kitab. Dengan diterapkannya metode bahsul masail, santri akan mendapatkan beberapa manfaat seperti mebuat para santri akan lebih kritis dalam berpikir, mengetahui masalah, mengetahui bagaimana cara memecahkan suatu masalah dalam ilmu qawaid (Ya'cub, Lailiyah, \& Hani'ah, 2020).

Dengan adanya penerapan metode ini maka akan membuat para santri mengingat-ingat serta menghubungkan pelajaran mereka yang telah lalu sebagai pengalaman yang dimiliki sebelumnya dengan tema atau permasalahan yang baru. 
Prinsip belajar menurut teori Gestalt ialah ketika Santri mengalami situasi baru, ketika menghadapinya Santri menggunakan pengalaman yang sebelumnya telah dimiliki, maka saat itulah Santri menghadirkan ingatannya yakni bagaimana seorang Santri melakukan konseptualisasi pengalamannya yang telah lalu kepada masa kini (Pautina, 2018). Teori Gestalt adalah merupakan aliran yang berpijak pada pengembangan paradigma berpikir yang mempunyai prinsip bahwa proses belajar adalah fenomena kognitif (Çeliköz, Erisen, \& Sahin, 2019).

Dari paparan tersebut dapat dilihat bahwa terdapat kesesuaian metode bahsul masail dengan teori kognitif dimana adanya proses berpikir secara kritis dalam benak santri. Hal senada juga terdapat dalam sebuah jurnal yang ditulis oleh Widdy Sukma Nugraha bahwa proses berpikir kritis dan penyelesaian masalah adalah bagian dari kognitif (Nugraha, 2018).

\section{Kesimpulan}

Dari penelitian ini, peneliti menyimpulkan beberapa point berikut: Langkahlangkah pembelajaran Qowaid dalam perspektif teori kognitif, yakni (1) Guru menjelaskan terlebih dahulu materi yang akan diajarkan menggunakan metode deduktif, (2) Guru memberikan contoh-contoh dari apa yang telah dijelaskan sebelumnya, (3) Guru meminta para santri untuk menghafal qowaid dan kosakata yang terdapat dalam kalimat atau teks yang mereka pelajari, (4) Guru tidak akan berpindah dari satu kaidah ke kaidah lain sebelum para santri benar-benar paham dengan satu kaidah terlebih dahulu. Adapun metode-metode pembelajaran Qowaid yang digunakan dalam perspektif teori kognitif, yakni (1) Metode Nahw wa Tarjamah (Gramatika Terjemah), (2) Metode deduktif, (3) Metode tanya jawab, (4) dan metode bahtsul masa'il.

\section{Referensi}

Aliyah, A. (2018). Fa'aa liyah Istikhdam al Thariqat al Ma'rifiyyah fi Ta'lim al Tarkib Lithalabah al Shaf al 'Asyir bil madrasah as sanawiyah al hukumiyah (MAN) as saniyah an namuzajiyyah Banjarmasin. Al Mi'yar: Jurnal Ilmiah Pembelajaran Bahasa Arab dan Kebahasaaraban, 1(1), 15-26. https://doi.org/10.35931/am.v1i1.81

Aliyah, A. (2018). Pesantren Tradisional Sebagai Basis Pembelajaran Nahwu Dan Sharaf Dengan Menggunakan Kitab Kuning. Al-Ta'rib: Jurnal Ilmiah Program Studi Pendidikan Bahasa Arab IAIN Palangka Raya, 6(1), 1-25. https://doi.org/10.23971/altarib.v6i1.966

Amin, N. F. (2018). Implikasi Pembelajaran Qawa'id Menggunakan Metode Bernyanyi pada Mahasiswa Jurusan Keperawatan UIN Alauddin Makassar. AlMaraji' : Jurnal Pendidikan Bahasa Arab, 2(2), 1-13.

Anidar, J. (2017). Teori Belajar Menurut Aliran Kognitif Serta Implikasinya Dalam Pembelajaran. Jurnal Al-Taujih : Bingkai Bimbingan dan Konseling Islami, 3(2), 8-16-16.

Çeliköz, N., Erisen, Y., \& Sahin, M. (2019). Cognitive Learning Theories with Emphasis on Latent Learning, Gestalt and Information Processing Theories. 
In Online Submission (Vol. 9, pp. 18-33). Retrieved from https://eric.ed.gov/?id=ED598366

Ekawati, D. (2019). Ragam Pemahaman Mahasiswa pada Pembelajaran Bahasa Arab. An Nabighoh: Jurnal Pendidikan Dan Pembelajaran Bahasa Arab, 21(02), 183-202. https://doi.org/10.32332/an-nabighoh.v21i02.1679

Ekawati, M. (2019). Teori Belajar Menurut Aliran Psikologi Kognitif serta Implikasinya dalam Proses Belajar dan Pembelajaran. E-Tech : Jurnal Ilmiah Teknologi Pendidikan, 7(2). https://doi.org/10.24036/et.v7i2.106979

Fahrurrozi, A. (2014). Pembelajaran Bahasa Arab: Problematika dan Solusinya. Arabiyat: Jurnal Pendidikan Bahasa Arab Dan Kebahasaaraban, 1(2), 161180. https://doi.org/10.15408/a.v1i2.1137

Gredler, M. E. (2012). Understanding Vygotsky for the Classroom: Is It Too Late? Educational Psychology Review, 24(1), 113-131. https://doi.org/10.1007/s10648-011-9183-6

Hanafy, M. S. (2014). Konsep Belajar dan Pembelajaran. Lentera Pendidikan : Jurnal Ilmu Tarbiyah dan Keguruan, 17(1), 66-79. https://doi.org/10.24252/lp.2014v17n1a5

Hawamadah, R., Q. (2010). Asalibu Tadris Lughatul Arabiyah baina Al Nazariyah Wa Tathbiq. 'Amman: Darul Muyassarah lin Nasyri wat Tawzi'.

Kurniawan, A. A. (2019). "An-Nahwu Sahl”: Media Pembelajaran Interaktif Mata Kuliah Tarkib Mukatstsaf Ii Berbasis Android Bagi Mahasiswa Jurusan Sastra Arab. Prosiding Konfererensi Nasional Bahasa Arab, 5(5), 431-436.

Ma'arif, M. (2010). Istiratijiyatu An Nazariyyah Al Ma'rifiyyah Litanmiyyati Maharatil Kalam. Malang: UIN-Maliki Malang Press.

Maijala, M. (2020). Culture teaching methods in foreign language education: Preservice teachers' reported beliefs and practices. Innovation in Language Learning and Teaching, 14(2), 133-149. https://doi.org/10.1080/17501229.2018.1509981

Makruf, I. (2016). Manajemen Integrasi Pembelajaran Bahasa Arab di Madrasah Berbasis Pondok Pesantren. Cendekia: Jurnal Kependidikan Dan Kemasyarakatan, 14(2), 265-280. https://doi.org/10.21154/cendekia.v14i2.570

Moleong, L. J., \& Creswell, K. (2006). Metode Penelitian. Bandung: PT RemajaRosdakarya.

Nugraha, W. S. (2018). Peningkatan Kemampuan Berpikir Kritis dan Penguasaan Konsep IPA Siswa SD Dengan Menggunakan Model Problem Based Learning. EduHumaniora / Jurnal Pendidikan Dasar Kampus Cibiru, 10(2), 115-127. https://doi.org/10.17509/eh.v10i2.11907

Nugrahani, F., \& Hum, M. (2014). Metode Penelitian Kualitatif. Solo: Cakra Books.

Pautina, A. R. (2018). Aplikasi Teori Gestalt Dalam Mengatasi Kesulitan Belajar Pada Anak. Tadbir: Jurnal Manajemen Pendidikan Islam, 6(1), 14-28. 
Ramelan, R. (2008). Bahasa dan kognisi Studi korelasional tentang pemahaman teks ekspositori dan berpikir deduktif dan induktif pada siswa SMA. Wacana, 10(1), 72-89. https://doi.org/10.17510/wjhi.v10i1.179

Rohayati, E. (2018). Efektivitas Penerapan Model Pembelajaran Advance Organizer berbasis Peta Konsep untuk Mata Kuliah Qawaid terhadap Daya Ingat Mahasiswa. Tapis: Jurnal Penelitian Ilmiah, 2(1), 128-155. https://doi.org/10.32332/tapis.v2i1.1117

Rosyid, M. F., \& Baroroh, R. U. (2019). Teori Belajar Kognitif dan Implikasinya dalam Pembelajaran Bahasa Arab. Al-Lisan: Jurnal Bahasa (e-Journal), 5(2), 180-198.

Sa'adah, N. (2019). Problematika Pembelajaran Nahwu Bagi Tingkat Pemula Menggunakan Arab Pegon. Lisanan Arabiya: Jurnal Pendidikan Bahasa Arab, 3(01), 15-32. https://doi.org/10.32699/liar.v3i01.995

Schunk, D. H., \& DiBenedetto, M. K. (2020). Motivation and social cognitive theory. Contemporary Educational Psychology, 60, 101832. https://doi.org/10.1016/j.cedpsych.2019.101832

Setyawan, C. E. (2015). Pembelajaran Qawaid Bahasa Arab Menggunakan Metode Induktif Berbasis Istilah-Istilah Linguistik. Journal Al-Manar, 4(2). https://doi.org/10.36668/jal.v4i2.54

Sugiyono. (2015). Metode Penelitian Pendidikan. Bandung: Alfabeta.

Teori Belajar Kognitif dan Penerapannya dalam Pendidikan. (2018, May 25). Retrieved May 2, 2020, from DasarGuru website: https://www.dasarguru.com/teori-belajar-kognitif-dan-penerapannya/

Tu'aimah, R. A. (2010). Al-marja' fy T'alìmil Lugah al-'Arabyyah Linnatiqìna Bi Luqatin Uhrā. Kairo: Darul Al-Fikri.

Tu'aimah, Rusydi Ahmad. (1989). Ta'lim al Arabiyah li ghairi an Nathiqina bihaa, manahijuhu wa asaalibuhu. Mansyuraat al munadzamah al islamiyah li tarbiyah wa al 'ulum wa as tsaqafah. Makkah: Jaami'ah Ummul Qura.

Tu'aimah, Rusydi Ahmad. (2010). Ta'limul Lughah Al Arabiyah Lin Nathiqina Biha: Manahijuhu wa Asalibuhu. al-Qahirah.

Tu'aimah, Rusydy Ahmad. (1989). Ta'lim al-Arabiyah Lighoiri al-Nathiqina Bilughat Ukhro. Kairo: Jami'ah al-Manshuroh.

Ushaily, A. A. (n.d.). Tharaiqu Ta'limil Lughah Al Arabiyyah Lin Nathiqina Bilugatin Ukhra. Riyadh: Radmuk.

Ya'cub, M., Lailiyah, N., \& Hani'ah, N. (2020). Manajemen Pembelajaran Berbasis Bahtsul Masail pada Mata Pelajaran Fiqih Ibadah di Pondok Pesantren Fathul Ulum Jombang. Al-Idaroh: Jurnal Studi Manajemen Pendidikan Islam, 4(1), 5273.

Zaenudin, A., \& Asror, K. (2019). Metode MNEMONIC: Solusi Kreatif Untuk Meningkatkan Pemahaman Nahwu Bagi Mahasiswa. 3(0), 184-195. 


\section{Copyright Notice}

Authors retain copyright and grant the journal right of first publication with the work simultaneously licensed under a Creative Commons Attribution 4.0 International License that allows others to share the work with an acknowledgement of the work's authorship and initial publication in this journal.

$$
\text { (c) (i) (9) }
$$




\section{HALAMAN INI SENGAJA DIKOSONGKAN}

